\title{
SOIL MOISTURE SENSOR CALIBRATION, ACTUAL EVAPOTRANSPIRATION, AND CROP COEFFICIENTS FOR DRIP IRRIGATED GREENHOUSE CHILE \\ PEPPERS
}

\author{
Harmandeep Sharma, Manoj K Shukla*, Paul W. Bosland, and Robert Steiner ${ }^{2}$ \\ Harmandeep Sharma, Graduate student, Plant and Environmental Sciences, MSC 3Q, P.O. Box \\ 30003, Las Cruces, NM 88003-8003. Tel: 575-646-2324; Fax: 575-646-6041; e-mail: \\ sharmah@nmsu.edu \\ Manoj K Shukla, Professor, New Mexico State University, Department of Plant and \\ Environmental Sciences, MSC 3Q, P.O. Box 30003, Las Cruces, NM 88003-8003. Tel: 575-646- \\ 2324; Fax: 575-646-6041; e-mail: shuklamk@nmsu.edu \\ Paul Bosland, Professor, New Mexico State University, Department of Plant and Environmental \\ Sciences, MSC 3Q, P.O. Box 30003, Las Cruces, NM 88003-8003. Tel: 575-646-2324; Fax: \\ 575-646-6041; e-mail: shuklamk@nmsu.edu \\ Robert L. Steiner, Professor, Economics and International Business Department, New Mexico \\ State University, MSC 3CQ, P.O. Box 30001, Las Cruces, NM 88003-8001. Tel: 575-646-4164; \\ Fax: 575-646-1915; e-mail: rsteiner@nmsu.edu
}

*Corresponding Author: Manoj K Shukla, Professor, New Mexico State University, Department of Plant and Environmental Sciences, MSC 3Q, P.O. Box 30003, Las Cruces, NM 88003-8003. Tel: 575-646-2324; Fax: 575-646-6041; e-mail: shuklamk@nmsu.edu 


\section{ABSTRACT}

Limited water supplies in arid regions put constraints on agriculture. In arid New Mexico, greenhouse chile pepper production has the potential for water and nutrient savings. The objectives of this study were to (1) compare two capacitance sensors-(Hydra probes and 5TM) and one TDR CS616 sensor, (2) compute actual evapotranspiration (ETa) for drip-irrigated chile peppers for three water treatments, and (3) develop new crop coefficients $\left(\mathrm{K}_{\mathrm{c}}\right)$ for the three growing seasons in a greenhouse study. Three water treatments were (1) control where water was applied near the surface using two drip emitters, (2) partial root zone drying vertical (PRDv) where subsurface irrigation was applied at $20 \mathrm{~cm}$ depth from soil surface, and (3) partial root zone drying compartment (PRDc) where roots were divided into two compartments and irrigation was switched between compartments after 15 days. Sensor-generated volumetric water contents $(\theta)$ were correlated with the gravimetrically determined $\theta$, and the new calibration coefficients improved the precision of $\theta$ estimates. From 2011 onward, irrigation amounts were adjusted to minimize deep percolation, and about 30\% less water was applied in 2014 as compared to the 2011 growing season but no significant differences were observed in transpiration rate and leaf temperature. The ratio of intercellular to ambient $\mathrm{CO}_{2}$ concentrations $(\mathrm{Ci} / \mathrm{Ca})$ was significantly correlated to transpiration rate and vapor pressure deficit in 2014 $(\mathrm{P}<0.05)$. ETa obtained from water balance and reference ET $(\mathrm{ETr})$ from Penman-Monteith developed the $\mathrm{K}_{\mathrm{c}}$ for drip-irrigated greenhouse chile peppers for three growing seasons. The maximum values of $\mathrm{K}_{\mathrm{c}}$ were about 1.4 during 2013 and 1.2 during 2014. The 2011 growing season was shorter and the maximum $\mathrm{K}_{\mathrm{c}}$ were closer to one. Crop coefficients for greenhouse grown chile peppers varied with growing seasons and irrigation treatment. Irrigation scheduling 
can be done based on the soil moisture or $\mathrm{K}_{\mathrm{c}}$ for the known growing season. This study demonstrated the water saving potential of PRD.

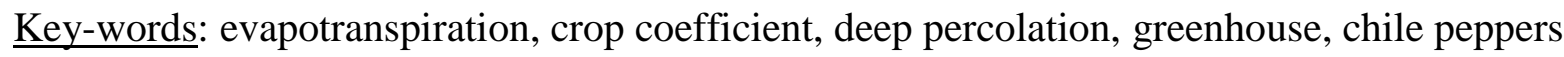

\section{Introduction}

Southern New Mexico is characterized by a semiarid to arid climate with an average of 3,700 hours of annual sunshine, high annual and diurnal temperatures, low relative humidity, and low average annual precipitation of 20-22 cm (Norman, 2000). Agriculture in arid regions primarily relies on irrigation and puts more constraints on the fresh surface and groundwater resources. Although New Mexico's aquifers have about 2.46 billion ha-m volume of fresh water, it is nonuniformly distributed. About $75 \%$ of the water is saline and cannot be used directly for irrigation (U.S. Geological Survey, 1988). Surface water availability in southern New Mexico is becoming increasingly limited, and environmental conditions are forcing the implementation of water management strategies for the sustainability of agriculture and food security in the region.

Irrigation scheduling can be done using a combination of soil, plant, and climate data (Deb et al., 2013). Nondestructive continuous soil water monitoring using time domain reflectometry (TDR) or capacitance-based sensors (Baumhardt et al., 2000), periodic monitoring of stem or leaf water potential using pressure bombs (Deb et al., 2013), and evapotranspiration (ET) estimates (Sammis et al., 2012) are used to schedule irrigation. These methods can optimize irrigation scheduling of crops and prevent water wastage and groundwater contamination due to nutrient leaching (Cepuder and Shukla 2002; Sharma et al., 2012).

Computing water balance within a soil system is very complex because soil water movement is a multidirectional process (Jackson, 1992; Maroux and Lafolie, 1998). The soil water balance method can be used to estimate actual ET (ETa) or deep percolation as an 
alternative to the expensive lysimeter method (Ochoa et al., 2007; Deb et al., 2012). However, the accuracy of data depends on the sensor quality to measure soil water contents (Burrough, 1989). Therefore, soil- and site-specific calibrations for soil water sensors are recommended (Topp et al., 1980; Evett and Parkin 2005).

Chile peppers, an important cash crop for New Mexico, are warm-season crops, sensitive to freezing temperatures at any growth stage, and require temperatures above $24^{\circ} \mathrm{C}$ and $10^{\circ} \mathrm{C}$ during the day and night, respectively (Bosland and Votava, 2012). There is a possibility of yearround chile pepper production in greenhouses using drip irrigation system. Crops grown in a greenhouse are managed differently than those grown outside, the microclimate inside the greenhouse is different than the outside, and crop coefficient $\left(\mathrm{K}_{\mathrm{c}}\right)$ values determined outside cannot be used for greenhouse crops. Furrow irrigated chile peppers in New Mexico require about $100-120 \mathrm{~cm}$ of water and about $315 \mathrm{~kg} \mathrm{~N} \mathrm{ha}^{-1}$ of URAN during growth period of about 150 days (Sharma et al., 2012). Drip irrigated chile peppers are reported to require about $95 \mathrm{~cm}$ of water (Wierenga, 1983). Greenhouse grown chile peppers in New Mexico are primarily surface irrigated, however, drip irrigation is used on a small scale. Because water is an increasingly scarce commodity in New Mexico, greenhouse production of chile peppers has the potential to apply water- and nutrient-saving strategies. Therefore, the objectives of this study were to compare three soil moisture content sensors; estimate chile pepper ETa; and determine $\mathrm{K}_{\mathrm{c}}$ values for efficient irrigation scheduling of drip-irrigated greenhouse chile peppers.

\section{MATERIALS AND METHODS}

\subsection{Study site and greenhouse}

This study was carried out in greenhouses located at New Mexico State University, Las Cruces, New Mexico $\left(32.2830^{\circ} \mathrm{N}\right.$ latitude, $106.7480^{\circ} \mathrm{W}$ longitude; elevation $\left.1186 \mathrm{~m}\right)$. The climate of the 
area is arid with mean annual temperature and precipitation of $15.83^{\circ} \mathrm{C}$ and $21.6 \mathrm{~cm}$, respectively (Norman, 2000; Sharma et al., 2015). The total area of the greenhouse is approximately $260 \mathrm{~m}^{2}$. The greenhouse is constructed with reinforced aluminum frame encased with single frame, corrugated, and oriented east to west. It has a double layer of polycarbonate copolymer sheets for insulation, a evaporative cooler and an exhaust on opposite ends, and heaters. A $70 \%$ shade-cloth is placed over the roof from May to early October to reduce the heat load in the greenhouse. Temperature inside the greenhouse is controlled by an automatic control system and the minimum and maximum cutoff temperatures are $26^{\circ} \mathrm{C}$ and $30^{\circ} \mathrm{C}$.

\subsection{Time Domain Reflectometry CS616 sensors}

TDR CS616 sensors that measured diurnal variation of soil water content for actual ETa estimation using water balance consisted of two parallel rods attached at the probe head $(300 \mathrm{~mm}$ long $\times 3.2 \mathrm{~mm}$ diameter) with $32 \mathrm{~mm}$ spacing. Voltage impulses are generated and reflected within the head and output is calculated based on reflections per second (frequency), which depends upon the dielectric permittivity $(\varepsilon)$ of the medium surrounding the probe. Because there is a big difference between the dielectric permittivity of air $(\varepsilon=1)$, soil (2.4-3.5), and water (80), travel times of the electromagnetic wave through soil vary with the soil water content (Chandler

et al., 2004). The sensor output reports the dielectric constant $(\tau)$ and is given as $\left(\mathrm{la}^{-1}\right)^{2}$, where la is the measured or apparent distance from the beginning to the end of the wave guide, and 1 is the real or physical lengths. The volumetric soil water content $(\theta)$ is obtained using the following second order quadratic equation (Campbell Scientific Inc. 2014; Shukla, 2014):

$\theta=\mathrm{A}+\mathrm{B} \tau+\mathrm{C} \tau^{2}$

where $\mathrm{A}$ is $-0.0663, \mathrm{~B}$ is -0.0063 , and $\mathrm{C}$ is 0.0007.

\subsection{Capacitance-based sensors}


Stevens Hydra probe (SDI-12) and Decagon 5TM are capacitance-based sensors that estimate the $\theta$ by measuring $\varepsilon$ and both also measure soil temperature. Furthermore, Hydra probes can measure bulk soil electrical conductivity (EC). Hydra probes and 5TM sensors are much smaller than TDR CS616 sensors. Hydra probe consists of four metal prongs, and each prong is $4.5 \mathrm{~cm}$ long and $0.3 \mathrm{~cm}$ wide. The $5 \mathrm{TM}$ sensor has three prongs, and each prong is 10 $\mathrm{cm}$ long and $3.2 \mathrm{~cm}$ wide. Deviation in calibration of a sensor occurs due to changes in soil texture, soil physical and chemical properties, soil temperature, and soil salinity. Calibration equations for Hydra sensors are given below (Stevens Water Monitoring System, Inc. 2007):

$\theta=\mathrm{A}+\mathrm{B} \varepsilon^{1 / 2}$

$\theta=\mathrm{A}+\mathrm{B} \varepsilon+\mathrm{C} \varepsilon^{2}+\mathrm{D} \varepsilon^{3}$

where A, B, C, and D are calibration constants and their values vary with soil texture (Bellingham, 2007). Like TDR sensors, soil-specific calibration was also suggested for capacitance-based sensors (Seyfried et al., 2005). 5TM sensors use the following Topp's equation to calculate $\theta$ from $\varepsilon$ (Topp et al. 1980)

$\theta=\mathrm{A}+\mathrm{B} \varepsilon+\mathrm{C} \varepsilon^{2}+\mathrm{D} \varepsilon^{3}$

where coefficient $\mathrm{A}$ is $-5.3 \times 10^{-2}, \mathrm{~B}$ is $2.92 \times 10^{-2}, \mathrm{C}$ is $-5.5 \times 10^{-4}$, and $\mathrm{D}$ is $4.3 \times 10^{-6}$ (Bellingham, 2007).

\subsection{Soil media for calibration and growth experiments}

Soil for sensor calibration as well as for growth experiments during 2011 through 2014 consisted of 1:1:1 mixture by volume of sand, loam, and peat moss. Soil was first sterilized in a PRO-GROW electric soil sterilizer at $60^{\circ} \mathrm{C}$ for 30 minute and then cooled down to air temperature before packing in the containers. All containers used were of the same size with a 26 $\mathrm{cm}$ diameter and $70 \mathrm{~cm}$ depth. Packing was done manually in $5 \mathrm{~cm}$ depth increments to obtain a 
homogeneous soil profile with an overall bulk density of $1.01 \pm 0.02 \mathrm{~g} \mathrm{~cm}^{-3}$. The bottom of each container was perforated, and perforations were covered with squared iron mesh $(5 \mathrm{~mm} \times 5 \mathrm{~mm})$ to prevent soil loss. Red lava rocks were placed on top of the mesh to ensure free drainage. There were three containers for sensor calibration, nine more for conducting growth experiments, and three more containers were used as border pots.

\subsection{Calibration of soil moisture sensors}

Measurement of soil water content is important for scheduling irrigation as well as conducting water balance analysis, therefore three different sensors were tested to find the one that could be used consistently. The sensor calibration was conducted in three separate pots not used for chile pepper growth experiments. CS616 sensors were installed in the containers at an angle of about $25^{\circ}$ and at depths of 0-15 and 15-30 cm from the soil surface. Hydra probes were installed vertically at 0-15 and 15-30 cm depths, and 5TM sensors at 0-15 cm depth only. Two Hydra probes and two 5TM sensors were installed at each depth, but only one CS616 sensor was installed at each depth. All data were recorded at 10 min intervals using a CR10X data logger. Each container during sensor calibration was irrigated from the top using two drip emitters. To determine $\theta$ gravimetrically, soil samples were collected using a push probe near the sensor probe ( $\sim 5 \mathrm{~cm}$ away), and the diameter of collected soil cores was about $2 \mathrm{~cm}$. Samples were collected from 0-15 and 15-30 cm depths daily from February 22 to March 31, 2013 and July 01 to July 31, 2013 for calibrating TDR CS616 and Hydra probes. For calibrating 5TM sensors, soil samples were collected at $0-15 \mathrm{~cm}$ depth before the initiation of irrigation, at the end of irrigation and then daily from January 16 to February 08, 2014 for several irrigation cycles. These holes were subsequently filled with similar dry soil. For all three sensors, new coefficients 
were obtained by using a least square optimization approach that minimized the sum of squared deviations between gravimetrically determined $\theta$ and sensor measured $\theta$.

\subsection{Soil properties}

Sand content of the soil mixture used for calibration and chile pepper transplants ('NuMex Joe E. Parker'; Capsicum annuum) varied from 72.4 to $76.4 \%$ with a mean of $75.57 \%$ and a standard error of $0.55 \%$. The silt content varied from 8 to $12 \%(8.86 \pm 0.55 \%)$ and clay content from 13.6 to $17.6 \%(15.60 \pm 0.40 \%)$. The saturated hydraulic conductivity varied from 2.84 to $4.04 \mathrm{~cm} \mathrm{~h}^{-1}\left(3.36 \pm 0.13 \mathrm{~cm} \mathrm{~h}^{-1}\right)$. The $\mathrm{pH}$ and EC of the soil mixture were 7.1 and 1.7 $\mathrm{dS} / \mathrm{m}$, respectively.

\subsection{Experimental design and irrigation treatments for growth experiments}

Pots for growing chile peppers were arranged in a completely randomized design with three replications per treatment. In each pot, one healthy "NuMex Joe E. Parker" chile pepper plant was transplanted at the center of the pot. There were three drip irrigation treatments for irrigating the chile peppers in the greenhouse. In the control treatment, containers were irrigated every other day with two drip emitters (adjustable from $0-0.09 \mathrm{~m}^{3}$ per hour at $103-207 \mathrm{kPa}$ Mini-Bubbler) placed on the soil surface (Fig. 1). In the partial rootzone drying vertical (PRDv) treatment, containers were irrigated with two subsurface drip emitters placed at $20 \mathrm{~cm}$ depth from the soil surface. Thus, the top $33 \%$ (top $20 \mathrm{~cm}$ out of total $60 \mathrm{~cm}$ soil depth) of the root system was exposed to drying, and wetting in this zone was only by capillary rise. Sub-surface irrigation was expected to decrease evaporation because of the lower hydraulic conductivity of top $20 \mathrm{~cm}$ soil layer. In the PRD compartment (PRDc) treatment, containers had split-root system and the roots were grown in two separate compartments. Irrigation was applied every 
other day for 15 days to one of the compartments and then switched to the other compartment for next 15 days.

CS616 sensors were used in year 2011 and 2013, while hydra sensors were used during 2014 growing season. In control treatment, soil moisture sensors (CS616 in 2011 and 2013; and hydra probes in 2014) were installed representing a depths of 0-30 cm and 30-60 cm. Similarly, in PRDv the soil moisture sensors were installed representing two depths i.e. 0-20 cm and 20-70 $\mathrm{cm}$. In contrast, soil moisture sensors were installed vertically in two separate compartments representing 0-40 $\mathrm{cm}$ depth in PRDc.

Irrigation was applied at one-day interval at the rate of $0.001 \mathrm{~m}^{3}$ per irrigation in the control as well as PRD treatments during 2011. However, in 2013, irrigation was applied at the same rate in the control and PRDv, but was only $0.0007 \mathrm{~m}^{3}$ per irrigation in the PRDc. During 2014 , irrigation was applied at two-day intervals at the rate of $0.001 \mathrm{~m}^{3}$ per irrigation in the control and $0.0007 \mathrm{~m}^{3}$ per irrigation in the PRDv and PRDc treatments. The irrigation amounts were adjusted in years 2013 and 2014 with an objective to minimize deep percolation.

\subsection{Plant Physiology, Actual and Reference Evapotranspiration}

Plant physiological measurements for transpiration rate, leaf temperature, ratio of intercellular to ambient $\mathrm{CO}_{2}$ concentrations $(\mathrm{Ci} / \mathrm{Ca})$, and vapor pressure deficit were made during 2013 and 2014 using LI-6400bXT portable system (LI-COR Biosciences, Lincoln, NE). These measurements were made five times during the growing season on illuminated healthy leaves (Sharma et al., 2015). The chile pepper pods were collected manually several times during the growing period and biomass was manually harvested at the end of the growing season (Sharma et al., 2015). 
The water balance was computed for chile peppers grown in containers in greenhouses during the three growing seasons of 2011, 2013, and 2014. The containers were arranged in a completely randomized design with three replications per treatment. Additional rows of plants were placed to eliminate border effects. Water balance equation was used to calculate the actual evapotranspiration (ETa) in individual containers:

$\mathrm{ETa}=\mathrm{P}+\mathrm{I}-\Delta \mathrm{S}-\mathrm{D}-\mathrm{R}$

where $\mathrm{P}$ is precipitation, $\mathrm{I}$ is irrigation, $\Delta \mathrm{S}$ is change in soil water storage, $\mathrm{D}$ is deep percolation, and $\mathrm{R}$ is runoff. The values of $\mathrm{P}$ and $\mathrm{R}$ were zero because the experiment was carried out in containers under controlled greenhouse conditions. The $\Delta \mathrm{S}$ was monitored using TDR soil moisture sensors during 2011 and 2013 and using Hydra probes during 2014, and D was measured manually by collecting all the water coming out of the bottom of each container. The amount of irrigation was adjusted with the aim of minimizing D in years 2013 and 2014.

To determine reference ET $\left(\mathrm{ETr}, \mathrm{mm} \mathrm{day}^{-1}\right)$ inside the greenhouse, a net radiometer, air temperature, and relative humidity sensors (CS500) were installed and data were recorded every 10 min using a CR10X data logger. Soil temperature sensors TMC6-HD were also installed in all treatments along with CS616. ETr values were also calculated using FAO-56 Penman Monteith (PM) for short grass (Allen et al., 1998) and Priestley and Taylor (PT) (1972) equations:

$\lambda E T r=\frac{\Delta(\mathrm{R} n-\mathrm{G})}{\Delta+\gamma\left(1+\frac{r_{S}}{r_{a}}\right)}+\frac{\rho_{a} c_{p}\left(e_{s}-e_{p}\right) / r_{a}}{\Delta+\gamma\left(1+\frac{r_{S}}{r_{a}}\right)}$

where $\lambda=$ latent heat of vaporization, $2.45\left(\mathrm{MJ} \mathrm{kg}^{-1}\right), \Delta=$ slope of the saturation vapor pressure curve $\left(\mathrm{kPa}^{\circ} \mathrm{C}^{-1}\right), \mathrm{R}_{\mathrm{n}}=$ net radiation at the crop surface $\left(\mathrm{MJ} \mathrm{m} \mathrm{m}^{-2}\right.$ day $\left.^{-1}\right), \mathrm{G}=$ soil heat flux $\left(\mathrm{MJ} \mathrm{m}^{-2}\right.$ day $\left.^{-1}\right)=0$, on daily basis $(\mathrm{FAO}, 56), \gamma=$ psychrometric constant $\left(\mathrm{kPa}^{\circ} \mathrm{C}^{-1}\right), \mathrm{r}_{\mathrm{s}}=($ bulk $)$ surface resistance $=70 \mathrm{~s} \mathrm{~m}^{-1}(\mathrm{FAO}, 56), \mathrm{r}_{\mathrm{a}}=$ aerodynamic resistance $\left(\mathrm{s} \mathrm{m}^{-1}\right), \rho_{\mathrm{a}}=$ mean air density at 
constant pressure $\left(\mathrm{kg} \mathrm{m}^{-3}\right), \mathrm{c}_{\mathrm{p}}=$ specific heat of air $\left(\mathrm{MJ} \mathrm{kg}^{-1}{ }^{\circ} \mathrm{C}^{-1}\right), \mathrm{e}_{\mathrm{s}}=$ saturation vapor pressure $(\mathrm{kPa})$, and $\mathrm{e}_{\mathrm{a}}=$ actual vapor pressure $(\mathrm{kPa})$.

In the PM equation, the first term is known as a radiation term and the second as an aerodynamic term that depends upon vapor deficit. Further details on the PM method can be referred in Qi et al. (2013). However, the PT equation neglects the aerodynamic term. The radiation-based PT equation used for ETr determination is:

$$
\lambda E \operatorname{Tr}=\alpha \frac{\Delta R n}{\Delta+\gamma}
$$

where coefficient $\alpha$ was calculated using the following equation (Holtslag and Van Ulden, 1983):

$$
\alpha=\frac{(1+\gamma / \Delta)}{1+\beta}
$$

where $\beta(=0.6)$ is the Bowen ratio (Holtslag and van Ulden, 1983).

The growing degree_day (GDD) values were calculated from the following equation:

$$
\text { GDD }=\left(\frac{\text { Daily max. temp }+ \text { Daily min. temp }}{2}\right)-\text { Base temp }
$$

For the chile pepper crop, maximum and minimum cutoff temperatures of $31^{\circ} \mathrm{C}$ and $5^{\circ} \mathrm{C}$, respectively, and base temperature of $5^{\circ} \mathrm{C}$ were used to calculate GDD (Sammis et al., 2012).

\subsection{Statistical Analysis}

The experiment was a completely randomized design. Analysis of variance (ANOVA) was performed on transpiration rate, leaf temperature, $\mathrm{Ci} / \mathrm{Ca}$, vapor pressure deficit, and components of water balance equation using proc GLM procedure of Statistical Analysis System (SAS) software (Version 9.0, SAS Institute, Inc., NC, USA) to detect an irrigation treatment effect. An F-test was applied at each measurement date to separate the irrigation treatment effect on physiological components at $5 \%$ significance level. The yearly differences were also evaluated and separated using LSD.

\section{RESULTS AND DISCUSSION}




\subsection{Sensor calibration}

Volumetric soil water content obtained using the manufacturer's calibration equation for CS616 sensors overestimated the gravimetrically measured $\theta$ at both depths (Fig. 2a; c). The maximum $\theta$ estimated using the manufacturer's equation were 0.51 and $0.56 \mathrm{~cm}^{3} \mathrm{~cm}^{-3}$ at $0-15$ and $15-30 \mathrm{~cm}$ depth, respectively, while gravimetrically measured $\theta$ values were $0.44 \mathrm{~cm}^{3} \mathrm{~cm}^{-3}$ at both depths. Stangl et al. (2009) and Udawatta et al. (2011) also reported overestimation (up to $67 \%$ ) of maximum $\theta$ with manufacturer calibration.

For soil-specific calibration, new coefficients A, B, and C were obtained for Eq. 1 at 0 $15 \mathrm{~cm}$ and 15-30 cm depths, separately (Table 1). Serrarens et al. (2000) and Deb et al. (2013) also reported large errors when a single calibration equation was used for different depths. The $\theta$ calculated using $\tau$ values and new calibration coefficients for CS616 produced better agreement with gravimetrically measured $\theta$ (Fig. $2 b$; d) with root-mean-squared error values decreasing from $0.140 \mathrm{~cm}^{3} \mathrm{~cm}^{-3}$ to $0.057 \mathrm{~cm}^{3} \mathrm{~cm}^{-3}$ and $0.181 \mathrm{~cm}^{3} \mathrm{~cm}^{-3}$ to $0.078 \mathrm{~cm}^{3} \mathrm{~cm}^{-3}$ at the depths of 0 15 and $15-30 \mathrm{~cm}$, respectively. Using new calibration equations, coefficients of determination $\left(R^{2}\right)$ values between measured and sensor-based $\theta$ were 0.50 and 0.57 at $0-15$ and $15-30 \mathrm{~cm}$ depths, respectively (Fig. 2b; d). Rüdiger et al. (2010) reported the reduced RMSE values for TDR from $0.14 \mathrm{~cm}^{3} \mathrm{~cm}^{-3}$ to $0.06 \mathrm{~cm}^{3} \mathrm{~cm}^{-3}$ with a newly developed general equation (Rüdiger et al., 2010). Similarly, higher RMSE values using the manufacturer's equation were also reported for CS615 (Stenger et al., 2005).

Hydra probe as well as 5TM sensor predicted $\theta$ values using the manufacturer's equation also overestimated the gravimetrically determined $\theta$ at both depths (Fig. 3; Fig. 4). Deviations between hydra probe-measured $\theta$ values and gravimetrically measured $\theta$ values became $< \pm 0.08$ $\mathrm{cm}^{3} \mathrm{~cm}^{-3}$ when new coefficients (Table 1) were used (Fig. 3). Similar results are reported by 
Bosch (2004) for coastal plain soils and Seyfried and Murdock (2004) for four different soils.

The $\theta$ calculated using the new coefficients for 5 TM sensor also provided a better representation of the gravimetrically determined $\theta$ (Fig. 4). New calibration coefficients developed for three sensors could be used for similar soil mixtures. However, type and amount of organic matter may require additional calibration because of its influence on the dielectric properties.

\subsection{Comparison of sensors}

Estimation of $\theta$ using capacitance sensors could differ from TDR because of the difference in measurement method as well as in the measurement frequency. The relationship between $\theta$ and $\varepsilon$ depends upon soil properties as well as measurement frequency (Chandler, 2004; Bosch, 2004). Capacitance probes are generally more sensitive to soil temperature and soil salinity due to the lower frequency. Secondly, measurement methods of these two sensors are different, and for the estimation of $\theta$, capacitance probes use real dielectric permittivity values while TDR uses period values.

CS616 sensors and Hydra probes were installed at the same depths in a container to record water contents from 26 July to 22 Sept., 2013 (Fig. 5a). The temporal variations of the two sensors were consistent, trends were similar, and values corresponded well with time of irrigation. A comparison of Hydra probes with CS616 sensors showed that $\mathrm{R}^{2}$ values between gravimetrically determined $\theta$ and sensor-measured $\theta$ were higher and RMSE values were lower for Hydra probes than CS616 sensors (Fig. 2; 3). Hydra probes are smaller than CS616 probes, easier to install for point measurement, and also measure soil temperature.

The 5TM sensors and Hydra probes were installed at the same depths and container, and continuous $\theta$ measurements were made from January 16 to Feb 08, 2014. Both sensors matched well to the time of irrigation and temporal trends were almost similar. However, large deviations 
were observed in the magnitude of $\theta$ values. Both wetting and drainage curves were underestimated by the 5TM sensor (Fig. 5b). Therefore, Hydra probes were preferred over CS616 and 5TM sensors for measuring $\theta$, change of water storage, and irrigation scheduling during 2013 and 2014 in this greenhouse pot based study.

\subsection{Plant Physiology, Water Balance, and Actual Evapotranspiration}

The transpiration rates varied temporarily but no significant differences were detected among the three water treatments during 2013 as well as 2014 (Fig. 6; P<0.05). The leaf temperatures and vapor pressure deficits also varied temporarily, but no significant differences among water treatments were detected during 2013 or $2014(\mathrm{P}<0.05)$. No significant differences in stomatal conductance and photosynthetic rates among normal and reduced water application were also reported in other studies (Kang, 2001). Some significant differences were noted for $\mathrm{Ci} / \mathrm{Ca}$ in all three treatments across measurement days $(\mathrm{P}<0.05)$. Water use efficiency is dependent upon $\mathrm{Ci} / \mathrm{Ca}$ ratios and the ratio is assumed to be dependent on photosynthetic pathways. During 2013, we did not find a significant correlation between transpiration rates and Ci/Ca but a significant correlation was obtained during 2014 (Fig. 7; P<0.05). In contrast, a significant correlation was obtained between $\mathrm{Ci} / \mathrm{Ca}$ and vapor pressure deficit during both 2013 and 2014 years of measurement $(\mathrm{P}<0.05)$ and $\mathrm{Ci} / \mathrm{Ca}$ was inversely related to the vapor pressure deficit.

The water balance equation (Eq. 5) has only ETa as an unknown factor. During 2011, the total amount of water applied in all three treatments was $106.3 \mathrm{~cm}$ (Sharma et al., 2015). Deep percolation (DP) was $14.6 \%$ and $11.3 \%$ lower in PRDv and PRDc, respectively, than the control (Sharma et al., 2015). However, higher ETa values were recorded for PRD treatments than the control (Fig. 7). Because water is applied below the soil surface, lower hydraulic connectivity in 
the upper soil layer in PRD treatments decreased evaporation and increased water storage and transpiration compared to the control. Similar decreases in liquid water flux with drying soil are also reported by other studies (Kang et al., 2000; Deb et al., 2011; Du et al., 2015). No differences in transpiration rates and leaf temperature when less water was applied support this argument. The detailed water balance data for 2013 and 2014 growing season are presented in Tables 2 and 3 .

Irrigation amounts were similar for control and PRDv treatments whereas about $30 \%$ less water was applied to PRDc during 2013 during each irrigation (Table 2). The total ETa was significantly higher for PRDv than PRDc and control $(\mathrm{P}<0.05)$. Total change in storage and total DP during 2013 were significantly lower for PRDc than PRDv and control $(\mathrm{P}<0.05)$. These values were consistent with the amounts of irrigation applied to the treatments as well as some variations in the saturated hydraulic conductivity of the soil. The same amount of irrigation water was applied to PRDv and the control, but DP was $14 \%$ less and actual crop ETa was $9 \%$ more than for the control due to the deeper rooting system and more roots in PRDv than the control (Sharma et al., 2015). During 2014, PRDv and PRDc treatments received 30\% less water than control during each irrigation (Table 3). The ET was significantly higher for the control than PRDv and PRDc $(\mathrm{P}<0.05)$. Again no significant differences in transpiration rates and leaf temperature when less water was applied indicates a reduction in evaporation in PRD treatments. Similar to 2013, change in water storage was significantly lower in PRDv than control or PRDc $(\mathrm{P}<0.05)$. No DP was recorded for PRD treatments and total DP was only $1 \mathrm{~cm}$ from control.

The growing season for 2011 was 140 days compared to 168 days for 2013 . The changes in storage using new calibration coefficients were also slightly higher in 2013 than 2011 because the soil profile depth for the 2011 experiment was $50 \mathrm{~cm}$ compared to $60 \mathrm{~cm}$ in 2013 . Average 
ECs of irrigation water and leachates from different pots were $06 \pm 0.05 \mathrm{dS} \mathrm{m}^{-1}$ and $1.42 \pm 0.07 \mathrm{dS}$ $\mathrm{m}^{-1}$, respectively, and irrigation and leachate waters were classified as good quality water (USDA Salinity Laboratory Riverside, California). Therefore, amounts of irrigations were reduced further during 2014 because leaching was not required and total DP was reduced. During 2014, water applied in PRDv and PRDc treatments was the same, but was 30\% less than that applied in the control. Irrigation interval was increased by one day compared to 2011 and 2013. Higher ETa values were recorded in the control compared to PRD treatments because of more applied water.

\subsection{Reference Evapotranspiration and Crop Coefficients}

In the absence of the direct ETr method, PM equation is recommended by FAO for comparison (Xu and Singh 2002; Sentelhas et al., 2010). However, the PT method is useful in absence of some meteorological variable such as wind speed or relative humidity. The comparison between average daily ETr values calculated using PM and PT equations from 29 April, 2013 to 14 Oct., 2013 (Fig. 8) showed that both methods followed similar trends, but the PT equation slightly underestimated ETr compared to the PM equation (Table 4).

Underestimated ETr values by the PT method could be due to its reliance on the solar radiation and temperature only and its neglect of the aerodynamics term.

The total crop ETa obtained by the water balance method was higher than the total ETr calculated from PM and PT methods during three years (Table 4). It could be due to the partial canopy cover that could have slightly increased the actual evaporation, and increases in leaf area index throughout the growing season. Variations in relative humidity inside the greenhouse could have also changed the actual evaporation. In this study, crop ETa values ranged from 55.85 to $59.73 \mathrm{~cm}$ during $2011,66.5$ to $72.58 \mathrm{~cm}$ during 2013, and 50.31 to $73.92 \mathrm{~cm}$ during 2014 . 
Using the water balance method, average chile pepper ETa values ranging from 26.3 to $71.1 \mathrm{~cm}$ were reported for furrow irrigation (Ertek et al., 2007). The $K_{c}$ values are usually obtained using crop ET with no limitations (no soil water stress or $\mathrm{f}=0$; and no salinity stress) in the absence of direct measurement (Sammis et al., 2012). Because this study was conducted in a greenhouse, direct measurement of ETa using water balance method was possible. The irrigation water was of good quality (EC $<0.6 \pm 0.05 \mathrm{dS} \mathrm{m}^{-1}$ ). Therefore, in this study, the ratio of crop ETa and $\mathrm{ETr}$ (from PM equation) values provided the actual $\mathrm{K}_{\mathrm{c}}$ values for the greenhouse chile pepper plants. The low irrigation water and leachate EC showed no salinity stress on chile pepper plants across water treatments. No significant differences in transpiration rates and leaf temperatures were observed for any of the five measurements. Therefore, soil water stress, already included in the estimate of the actual crop Eta, was similar among treatments. This was further supported by no significant differences in the pod and biomass yields of chile pepper among three water treatments for both years (Sharma et al., 2015). The $\mathrm{K}_{\mathrm{c}}$ curves were developed for the drip irrigated greenhouse chile peppers under three different irrigation treatments for the growing seasons of 2011, 2013, and 2014, separately, because amount of irrigation water applied varied among treatments.

Daily $\mathrm{K}_{\mathrm{c}}$ data were plotted against daily GDD, separately by treatment and year, and a third order polynomial equation produced the best fit for each treatment and year (Table 5). The daily $\mathrm{K}_{\mathrm{c}}$ data were combined for each year and plotted against daily GDD, and a third order polynomial equation was the best fit for all three years $(\mathrm{P}<0.001$; Fig. 9). The GDD-based equations for $\mathrm{K}_{\mathrm{c}}$ are considered superior because of the easily available temperature data from weather stations. The GDD values varied among three years because of the differences in growing seasons and growing periods (Fig. 9). These values were minimum for 2014 because the 
growing season, November 2013 to April 2014, corresponded to the winter and spring seasons, with lower temperature conditions and a growing period of about 135 days; the values were maximum for 2013 because growing season was during summer (April to October 2013) (Fig. 9). The polynomials showed some difference among the treatments, irrigation amounts, as well as between the growing seasons. Orgaz et al. (2005) study supported these results.

In 2011, peak $\mathrm{K}_{\mathrm{c}}$ value varied between 0.91 and 1.19 , with the maximum value in the control and minimum in PRDc. ETr values were the same for all treatments; however, crop ETa values were lower in PRD treatments than the control. The mean maximum $\mathrm{K}_{\mathrm{c}}$ value was obtained as 1.05 , which was identical to the value of 1.05 reported by UC Vegetable Research \& Information Center in California. Chile peppers were transplanted on June 13, 2011 at the fifth leaf stage, and during July and August — warm months with high GDD — chile pepper plants were still growing and actual chile pepper ET was close to the reference ET. The comparison of inside and outside greenhouse radiations showed a maximum difference of about $25 \%$.

The peak $\mathrm{K}_{\mathrm{c}}$ values recorded in 2013 were $1.48,1.56$, and 1.30 for the control, PRDv, and PRDc, respectively. The values were higher in 2013 compared to 2011. Higher irrigation volumes were applied to control and PRDv during 2013. Also in 2013, the chile peppers were transplanted in April at the fifth leaf stage, and during the months of high GDD the chile pepper crop was fully grown and crop ETa was high. The comparison of inside and outside greenhouse net radiations showed only about $7 \%$ difference, which could have also contributed to the higher $\mathrm{K}_{\mathrm{c}}$ values. In a greenhouse experiment in Spain, $\mathrm{K}_{\mathrm{c}}$ values of 1.4 were reported for sweet pepper (Orgaz et al., 2005). In contrast, in a furrow-irrigated field, chile pepper $\mathrm{K}_{\mathrm{c}}$ values up to 1.76 were reported (Ertek et al., 2007). 
During 2014, a similar trend of $\mathrm{K}_{\mathrm{c}}$ was observed as in 2011: the peak $\mathrm{K}_{\mathrm{c}}$ values varied from 1.21 to 1.28 , with maximum value in the control and minimum in PRDv. The difference between inside and outside radiation was again 25\% in 2014. Peak values in 2014 were lower than 2013 because of less frequent irrigation, and the actual ETa values were also lower than 2013 due to the decreases in evaporation. This study showed that even in a greenhouse crop coefficients are functions of the growing season as well as the duration, and therefore $\mathrm{K}_{\mathrm{c}}$ values corresponding to the growing season should be used for irrigation scheduling.

\section{CONCLUSIONS}

Water conservation through efficient irrigation scheduling is required for sustaining greenhouse chile pepper production in the arid areas of the world. This study was conducted to test three potential sensors to identify one that could be used for irrigation scheduling based on soil water content in a greenhouse. Hydra probes were found to be the superior option for measuring $\theta$ and soil temperature. Significant differences were noted in Eta values but no significant differences for transpiration rates and leaf temperatures for chile peppers among treatments in the greenhouse indicated decreases in evaporation in PRD treatments. The maximum values of $\mathrm{K}_{\mathrm{c}}$ were 1.0 in 2011 with short growing season, and 1.4 and 1.2 from the control and PRD treatments during 2013 and 2014. More experiments should be conducted to verify the crop coefficients developed in this greenhouse study. Soil moisture contents or crop coefficients corresponding to the actual growing season can be used to schedule irrigation and reduce water loss to sustain greenhouse chile pepper production in arid areas. This study demonstrated the water saving potential of PRD.

\section{ACKNOWLEDGEMENT}


Authors thank New Mexico State University Agricultural Experiment Station and Nakayama Chair endowment for the support. Thanks are also due to NMSU Vice President of Research's GREG program for graduate student support. This work was partially supported by the USDA National Institute of Food and Agriculture, Hatch project 1006850.

\section{REFERENCES}

Allen, R. G., Pereira, L. S., Raes, D., and Smith, M. 1998. Crop evapotranspiration guidelines for computing crop water requirements. Irrig. Drain Paper 56. UN-FAO, Rome, Italy.

Bakundukize, C., Camp, M. V., and Walraevens, K. 2011. Estimation of groundwater recharge in bugesera region (Burundi) using soil moisture budget approach. Geologica Belgica., 14(1-2), 85-102.

Baumhardt, R. L., Lascano, R. J., and Evett, S. R. 2000. Soil material, temperature, and salinity effects on calibration of multisensory capacitance probes. Soil Sci. Soc. Am. J., 64, 19401946.

Bellingham, K. 2007. The stevens hydra probe inorganic soil calibrations. Stevens Water Monitering Systems Inc. Portland, Oregon. http://www.stevenswater.com/catalog/products/soil_sensors/datasheet/The\%20Stevens\% 20Hydra\%20Probe\%20Inorganic\%20Soil\%20Calibrations.pdf. Accessed on 21 Aug, 2015.

Bosch, D. D. 2004. Comparison of capacitance-based soil water probes in coastal plain soils. Vadose Zone J., 3, 1380-1389.

Bosland, P.W. and E.J. Votava. 2012. Peppers: vegetable and spice capsicums. 2nd edition. CAB International, United Kingdom 230 pp. 
Burrough, P. A. 1989. Matching spatial databases and quantitative models in land resource assessment. Soil Use Manage., 5, 3-8.

Campbell Scientific Inc. 2014. CS616 and CS625 Water Content Reflectometers, Revision 8/06. Campbell Scientific http://www.campbellsci.com/documents/manuals/cs616.pdf. Accessed 7 Aug 2014.

Cepuder, P., and Shukla, M. K. 2002. Groundwater nitrate in Austria: A case study in Tullnerfeld. Nutr. Cycl. Agroecosys. 64(3), 301-315.

Chandler D.G. 2004. Field calibration of water content reflectometers. Soil Sci. Soc. Am. J. 68, $1501-1507$.

Chandler, D. G., Seyfried, M., Murdock, M., and McNamara, J. P. 2004. Field calibration of water content reflectometers. Soil Sci. Soc. Am. J., 68, 1501-1507.

Deb, S. K., Shukla, M. K., Sharma, P., and Mexal, J. G. 2013. Soil water depletion in irrigated mature pecans under contrasting soil textures for arid Southern New Mexico. Irrig Sci., $31,69-85$.

Deb, S.K., Shukla, M. K., Sharma, P., and Mexal, J. 2011. Coupled liquid water, water vapor, and heat transport simulations in an unsaturated zone of a sandy loam field. Soil Sci., 176(8), 387-398.

Deb, S. K., Shukla, M. K., and Mexal, J. G. 2012. Simulating deep percolation in flood-irrigated mature orchards with RZWQM2. Transactions of the ASABE. 55 (6), 2089-2100.

Du, T.. Kang, S, Zhang, J., and Davies, W.J. 2015. Deficit irrigation and sustainable waterresource strategies in agriculture for China's food security. J. Experimental Botany, 66(8), 2253-2269. 
Ertek, A., Sensoy, S., Gedik, I., and Kücükyumuk, C. 2007. Irrigation scheduling for green pepper (Capsicum аппиит L.) grown in field conditions by using class-a pan evaporation values. American-Eurasian J. Agric. \& Environ. Sci., 2(4), 349-358

Evett, S. R., and Parkin, G. W. 2005. Advances in soil water content sensing: The continuing maturation of technology and theory. Vadose Zone J., 4, 986-999.

Francesca, V., Osvaldo, F., Stefano, P., and Paola, R. P. 2010. Soil moisture measurements: comparisons of instrumentation performances. J. Irrig. Drain Eng., 136 (2), 81-89.

Hillhorst, M. A. 2000. A pore water conductivity sensor. Soil Sci. Soc. Am. J., 64, 1922-1925.

Holtslag, A. A. M., and van Ulden, A. P. 1983. A simple scheme for daytime estimates of the surface fluxes from routine weather data. J. Clim. Appl. Meteorol., 22, 517- 529.

Hornbuckle, B. K. and Logsdon, S. D. 2006. Soil moisture probes for a dispersive soil, Proc., TDR 2006, Purdue University, West Lafayette, USA, Sept. 2006, Paper ID 13, 14 p., https://engineering.purdue.edu/TDR/Papers.

Jackson, C. R. 1992. Hillslope infiltration and lateral downslope unsaturated flow. Water Resour. Res., 28(9), 2533-2539.

Kang, S., L. Zhang, X. Hu, Z. Li, and P. Jerie. 2001. An improved water use efficiency for hot pepper grown under controlled alternate drip irrigation on partial roots. Sci. Hort. 89, $257-267$.

Kang, S., Liang, Z., Pan, Y., Shi, P., and Zhang, J. 2000. Alternate furrow irrigation for maize production in an arid area. Agric.Water Manage., 45(3), 267-274.

Maraux, F., and Lafolie, F. 1998. Modeling soil water balance of a maize-sorghum sequence. Soil Sci. Soc. Am. J., 62(1), 75-82. 
Morgan, C. P., and Stolt, M. H. 2004. A comparison of several approaches to monitor watertable fluctuations. Soil Sci. Soc. Am. J., 68(2), 562-566.

Nachabe, M., Shah, N., Ross, M., and Vomacka, J. 2005. Evapotranspiration of two vegetation covers in a shallow water table environment. Soil Sci. Soc. Am. J., 69(2), 492-499.

Norman, R. 2000. Climate Guide, Las Cruces. Agriculture Exp. Station Res. Rep. 749., College of Agriculture and Home Economics, Las Cruces, NM.

Ochoa, C. G., Fernald, A. G., Guldan, S. J., and Shukla, M. K. 2007. Deep percolation and its effects on shallow groundwater level rise following flood irrigation. Transaction ASABE. 50(1), 73-81.

Orgaz, F., Fernandez, M.D., Bonachela, S., Gallardo, M., and Fereres, E. 2005. Evapotranspiration of horticultural crops in an unheated plastic greenhouse. Agric Water Manag., 73, 81-96.

Plauborg, F. 1995. Evaporation from bare soil in a temperate humid climate-measurement using microlysimeter and time domain reflectometry. Agric. For. Meteorol., 76, 1-17.

Qi, R., Kang, S., Du, T., Tong, L, Hao, X., Chen, R., Chen, J., and Li, F. 2013. Effect of convection on the Penman-Monteith model estimates of transpiration of hot pepper grown in solar greenhouse. Scientia Hort. 160, 163-171.

Roth, C. H., Malicki, M. A., and Plagge, R. 1992. Empirical evaluation of the relationship between soil dielectric constant and volumetric water content as the basis for calibrating soil moisture measurements by TDR. J. Soil Sci., 43(1), 1-13.

Rudiger, C., Western, A.W., Walker, J.P., Smith, A.B., Kalma, J.D., and Willgoose, G.R. 2010. Towards a general equation for frequency domain reflectometers. J. of Hydrology, 383, 319-329. 
Sammis T., Sharma, P., Shukla, M.K., Wang, J., and Miller, D. 2012. A water balance trickle irrigation scheduling model. Agric. Water Manage., 113, 30-37.

Sentelhas, P. C., Gillespie, T. J., and Santos, E. A. 2010. Evaluation of FAO Penman-Monteith and alternative methods for estimating reference evapotranspiration with missing data in Southern Ontario, Canada. Agric. Water Manage., 97, 635-644.

Serrarens, D., MacIntyre, J. L., Hopmans, J. W., and Bassoi, L. H. 2000. Soil moisture calibration of TDR multilevel probes. Sci Agric., 57, 349-354.

Seyfried, M. S., Grant, L. E., Du, E., and Humes, K. 2005. Dielectric loss and calibration of the Hydra Probe soil water sensor. Vadose Zone J., 4, 1070-1079.

Seyfried, M. S., and Murdock, M. D. 2004. Measurement of soil water content with a 50-MHz soil dielectric sensor. Soil Sci. Soc. Am. J., 68, 394-403.

Sharma, H., Shukla, M. K., Bosland, P., and Steiner, R. L. 2015. Physiological responses of greenhouse-grown drip irrigated chile pepper under partial root zone drying. HortScience. $50(8), 1224-1229$.

Sharma, P., Shukla, M. K., Sammis, T. W., Steiner, R. L., and Mexal, J. G. 2012. Nitratenitrogen leaching from three specialty crops of New Mexico under furrow irrigation system. Agric. Water Manage., 109, 71-80.

Shukla, M.K. 2014. Soil Physics an Introduction. CRC Press, Boca Raton, FL, USA. ISBN $9781439888421, \mathrm{p} 478$.

Stangl, R., Buchan, G. D., and Loiskandl, W. 2009. Field use and calibration of a TDR-based probe for monitoring water content in a high-clay landslide soil in Australia. Geoderma., $150,23-31$. 
Stevens Water Monitoring Inc. 2007. Comprehensive Stevens hydra probe users manual. http://www.stevenswater.com/catalog/products/soil_sensors/manual/Hydra\%20Probe\%20 Manual\%2092915\%20July\%202007.pdf . Accessed on 8 Aug 2014.

Stenger, R., Barkle, G., and Burgess, C. 2005. Laboratory calibrations of water content reflectometers and their in-situ verification. Aust. J. Soil Res., 43(5), 607-615.

Topp, G. L., Davis, J. L., and Annan, A. P. 1980. Electromagnetic determination of soil water content: Measurements in coaxial transmission lines. Water Resour. Res., 16, 574-582.

Udawatta, R. P., Anderson, S. H., Motavalli, P. P., and Garrett, H. E. 2011. Calibration of a water content reflectometer and soil water dynamics for an agroforestry practice. Agroforest Syst., 82, 61-75.

U. S. Geological Survey (USGS). 1988. National water summary 1986 - Hydrologic events and ground-water quality. USGS Water Supply Paper 2325. Available online http://pubs.er.usgs.gov/publication/wsp2325 Accessed on 7 Aug, 2014.

Wierenga, P.J. 1983. Yield and quality of trickle irrigated chile. New Mexico State University Agricultural Experiment Station Bulletin no. 703, 16pp.

Xu, C. Y., and Singh, V. P. 2002. Cross comparison of empirical equations for calculating potential evapotranspiration with data from Switzerland. Water Resour. Manag., 16, 197219. 


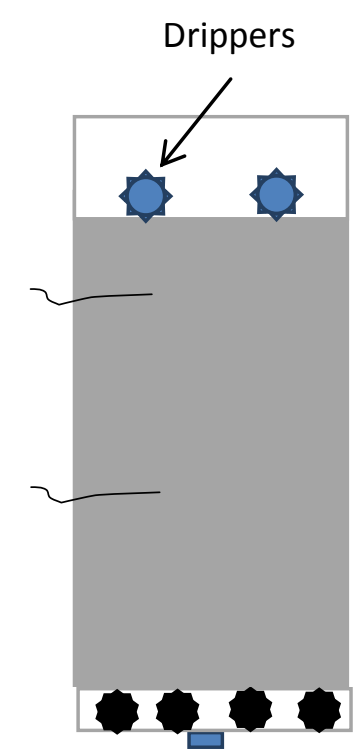

a) Control

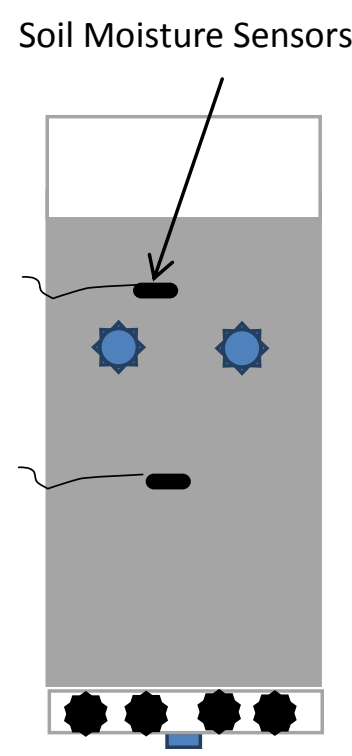

b) PRDV

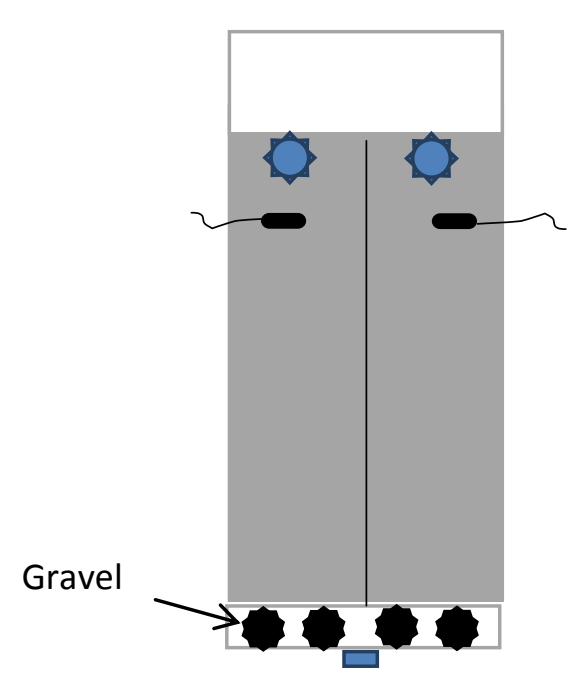

c) PRDc

Fig. 1. Schematic of the experimental pots showing the locations of drippers, soil moisture sensors, gravel at the bottom and the drain for (a) control where drippers were placed on soil surface, (b) partial root zone drying vertical (PRDv) where drippers were placed at $20 \mathrm{~cm}$ depth from soil surface, and (c) partial root zone drying compartment (PRDc) where drippers were placed near soil surface $(0-5 \mathrm{~cm})$ 


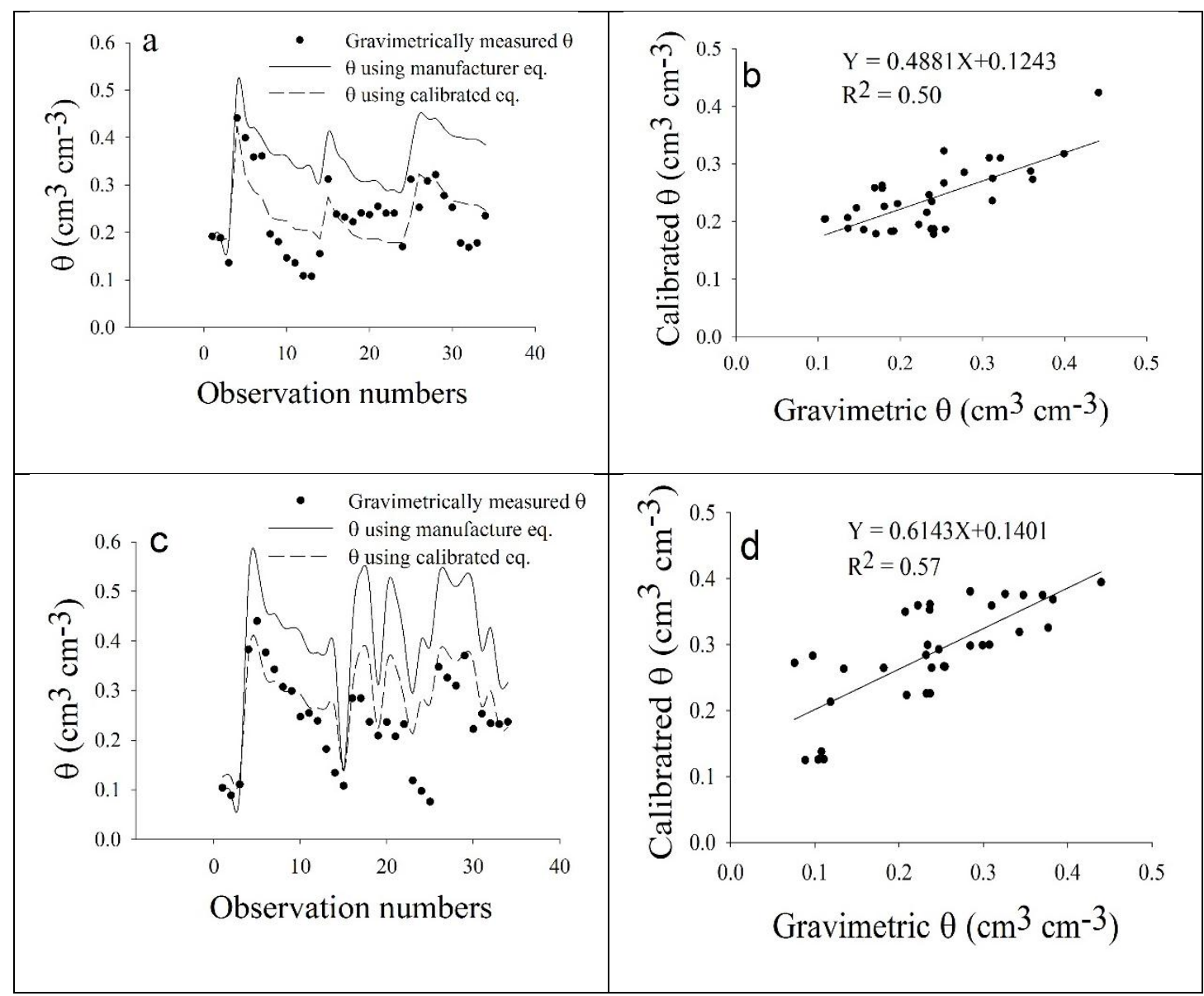

Figure 2. Comparison of gravimetrically measured volumetric water content $(\theta)$, and $\theta$ calculated using manufacturer and new calibrated equation for CS616 at the depths of (a; b) 0-15 cm and (c; d) 15-30 cm, respectively during Feb 22 to March 31, 2013. In c and d developed calibration were used to obtain $\theta$ on $\mathrm{Y}$-axis. 


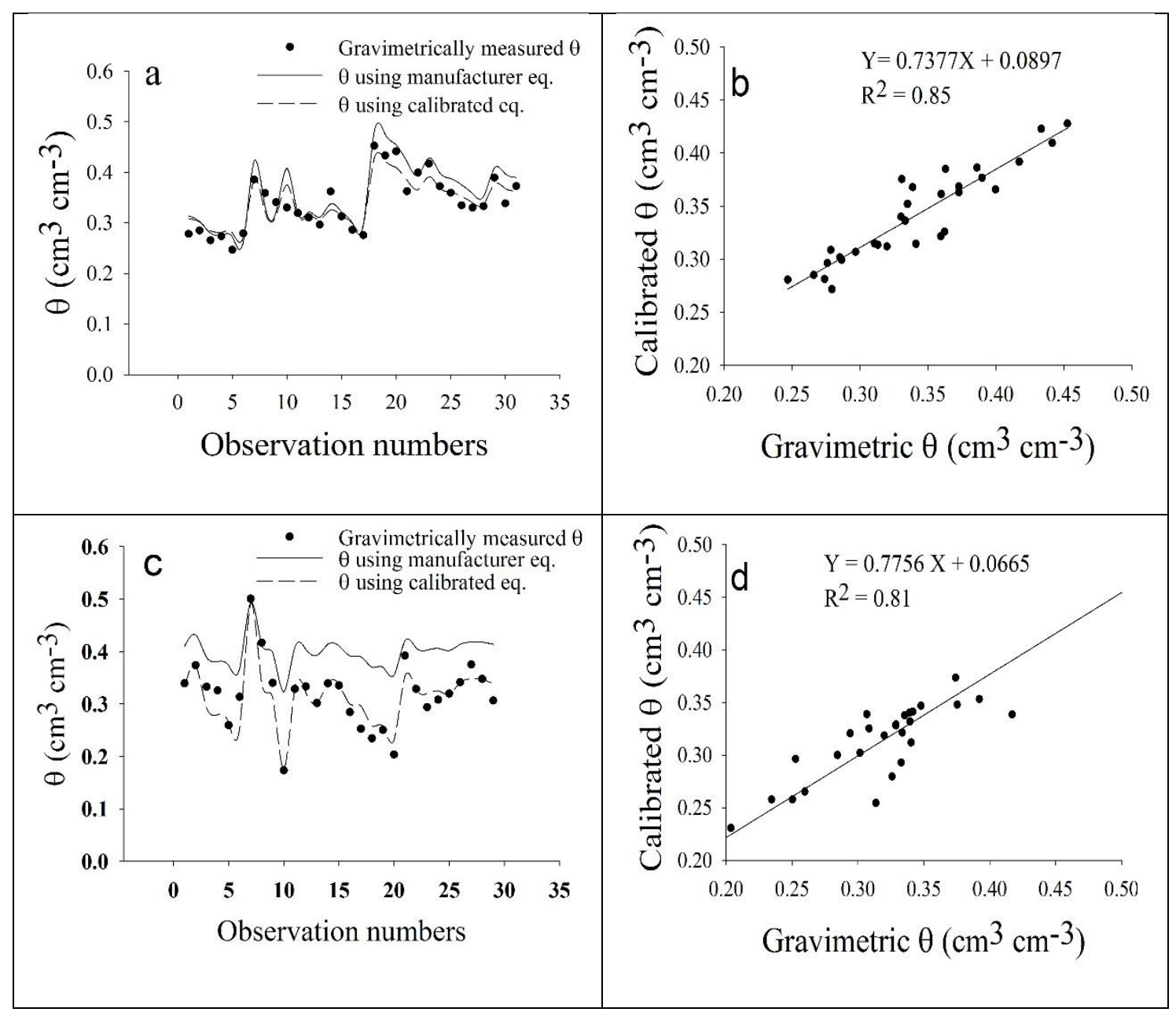

Figure 3. Comparison of gravimetrically measured volumetric water content $(\theta)$ with $\theta$ obtained using manufacturer and calibrated equation for hydra probes at the depths of $(\mathrm{a} ; \mathrm{b}) 0-15 \mathrm{~cm}$ and (c; d) 15-30 cm, respectively during July 01 to 31,2013 . In c and d developed calibration were used to obtain $\theta$ on Y-axis. 


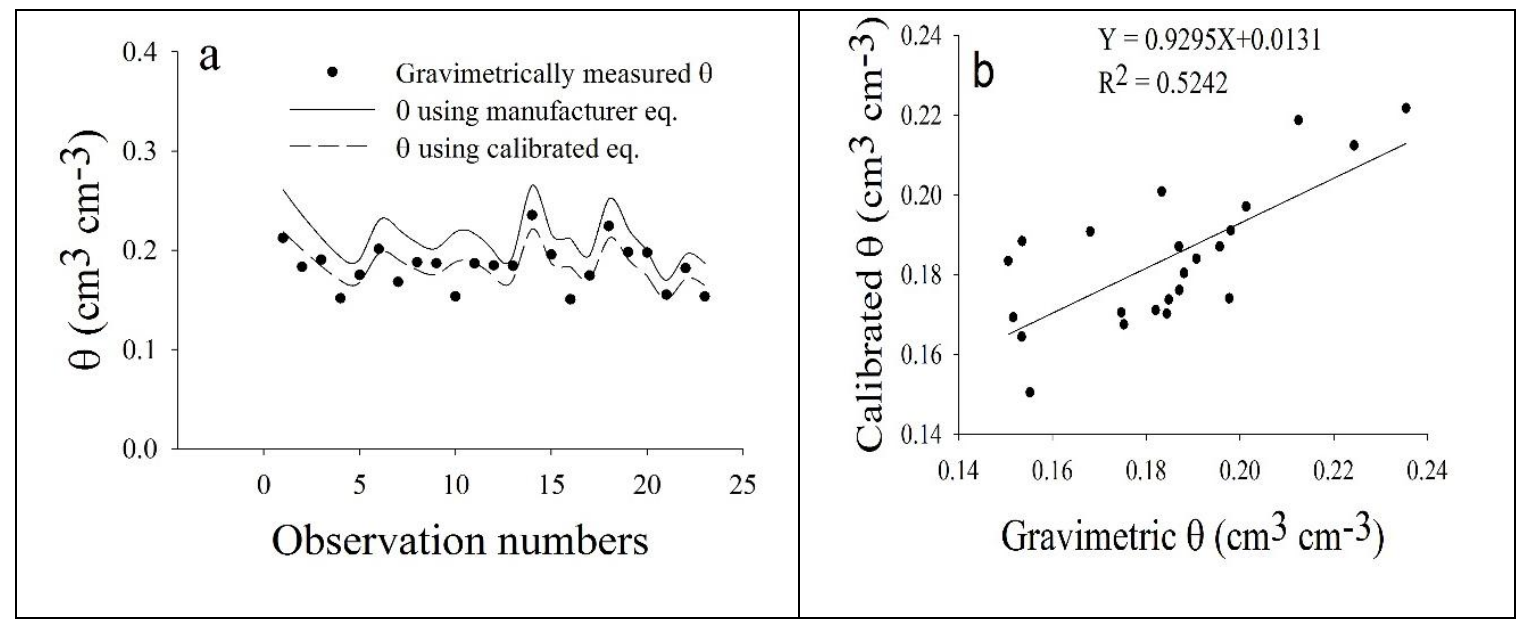

Figure 4. (a) Comparison of gravimetrically measured volumetric water content $(\theta)$ and $\theta$ obtained by 5 TM sensor using manufacturer equation (1.5) and calibrated equation (1.10) at the depth of 0-15 cm during Jan 16 to Feb 07, 2014. (b) Relationship between $\theta$ by 5TM sensor using developed calibrated equation (1.10) and the $\theta$ measured using gravimetric method at $0-15$ $\mathrm{cm}$ 


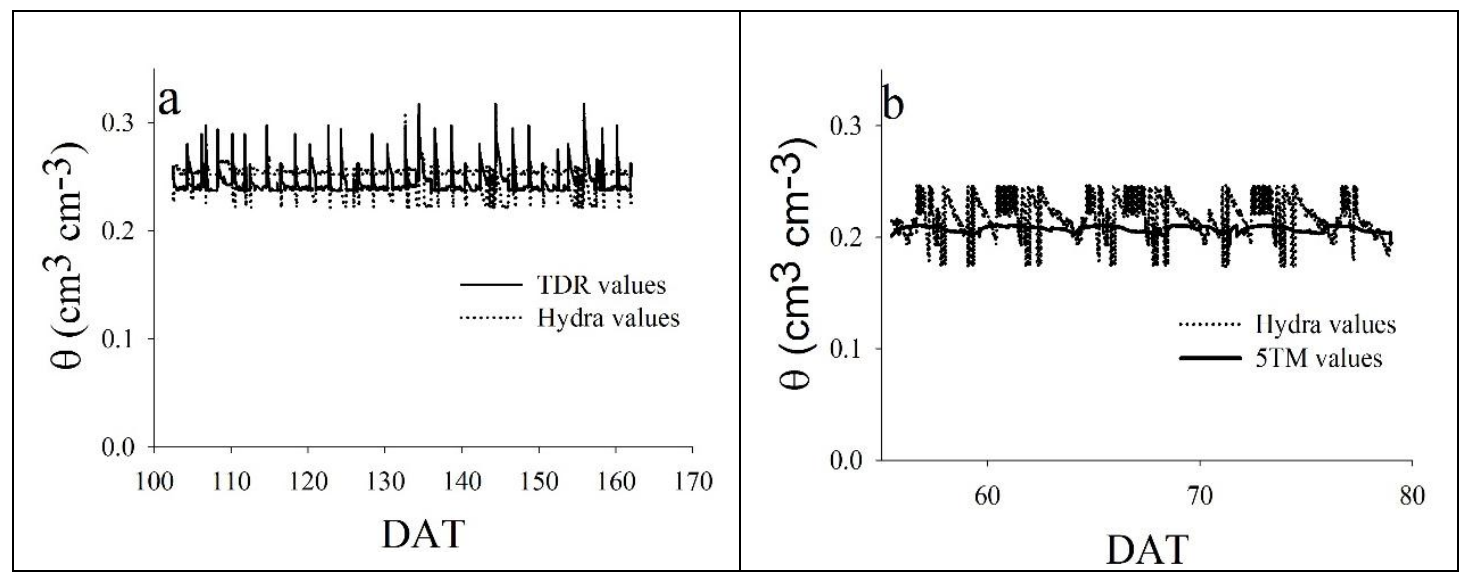

Figure 5. (a) Comparison of volumetric water content $(\theta)$ values obtained using TDR and hydra probe during time-period DAT (102 to 161) and (b) $\theta$ values obtained using hydra probe and 5TM sensor during time-period DAT (55 to 79) 


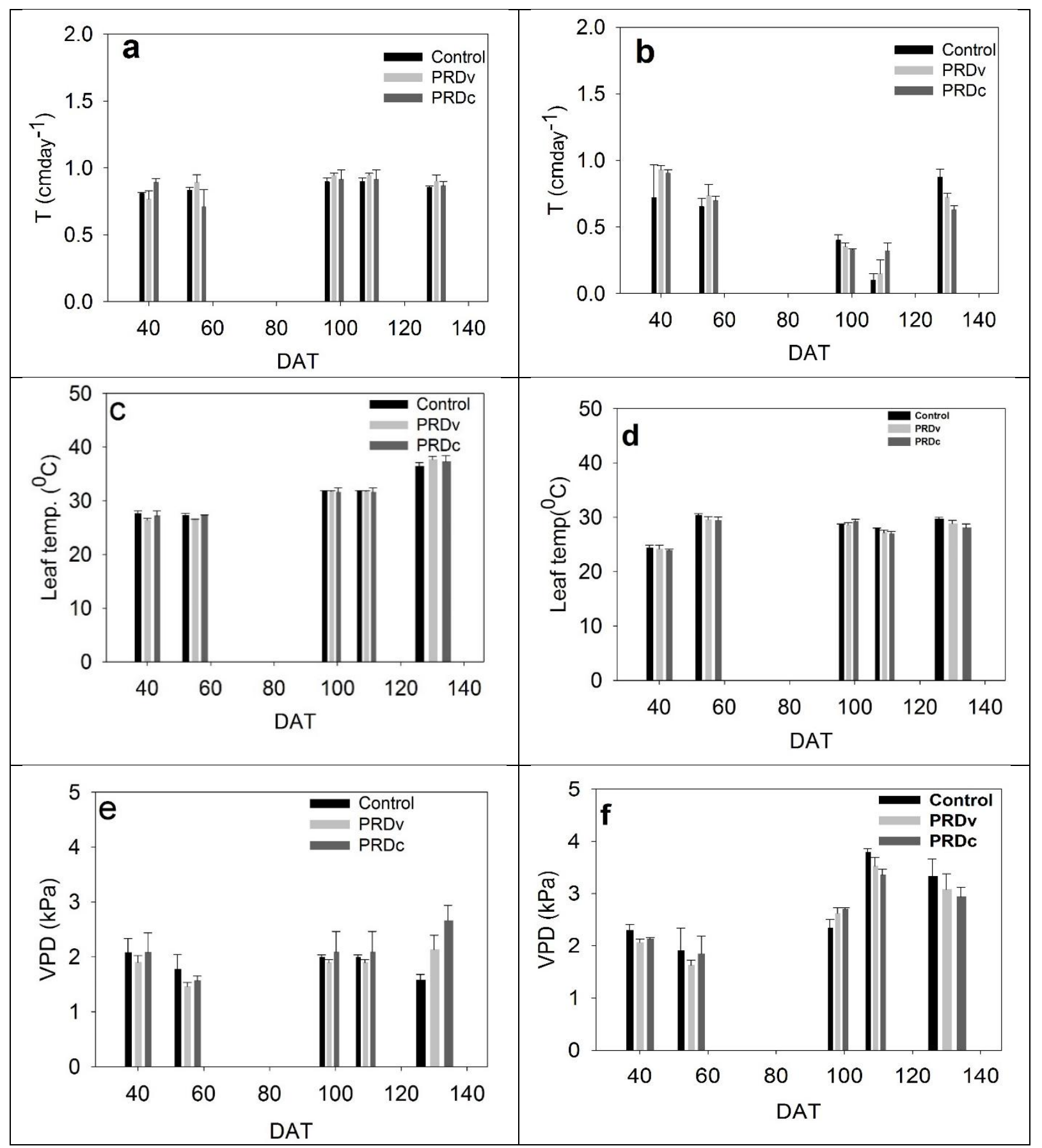

Figure 6. Transpiration rates, T, (a, b), leaf temperature (c, d), and vapor pressure deficit, VPD, $(\mathrm{e}, \mathrm{f})$ ) for the greenhouse grown chile under three water treatments. $\mathrm{PRD}_{\mathrm{v}}$ is Partial rootzone drying vertically, and $\mathrm{PRD}_{\mathrm{c}}$ is partial rootzone drying compartment. No significant differences were observed at

$\mathrm{P}<0$. 


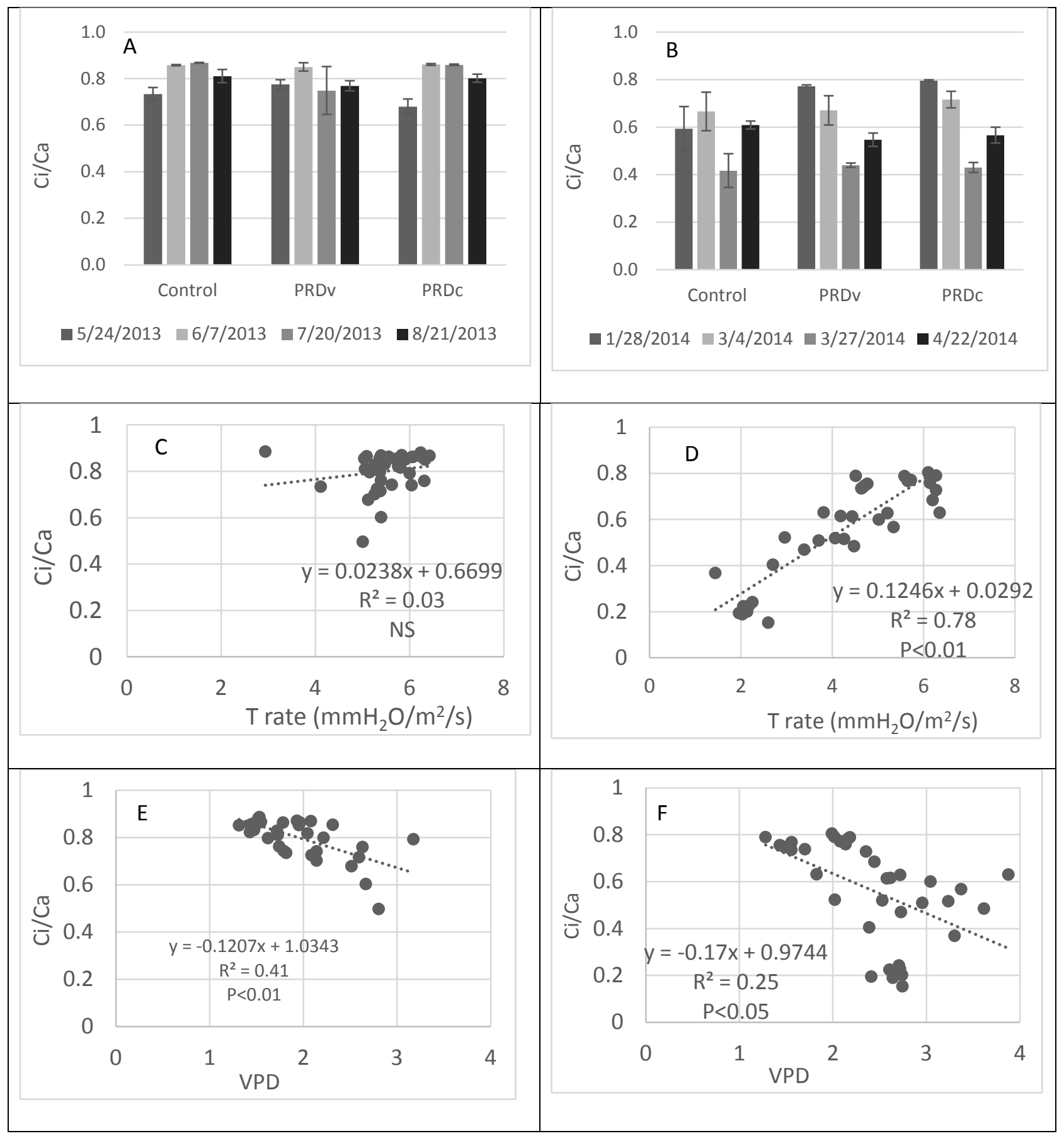

Figure 7. The ratio of intercellular to ambient $\mathrm{CO}_{2}$ concentrations $(\mathrm{Ci} / \mathrm{Ca})$ for the greenhouse grown chile peppers measured four times during (A) 2013 and (B) 2014. Relationship between $\mathrm{Ci} / \mathrm{Ca}$ and Transpiration (T) rate during (C) 2013 and (D) 2014. Relationship between Ci/Ca and vapor pressure deficit (VPD) during (E) 2013 and (F) 2014. $\mathrm{PRD}_{\mathrm{v}}$ is Partial rootzone drying 
vertically, and $\mathrm{PRD}_{\mathrm{c}}$ is Partial rootzone drying compartment. Note: significant differences were observed within each treatments $f$ day of measurement during both years at $\mathrm{P}<0.05$. 


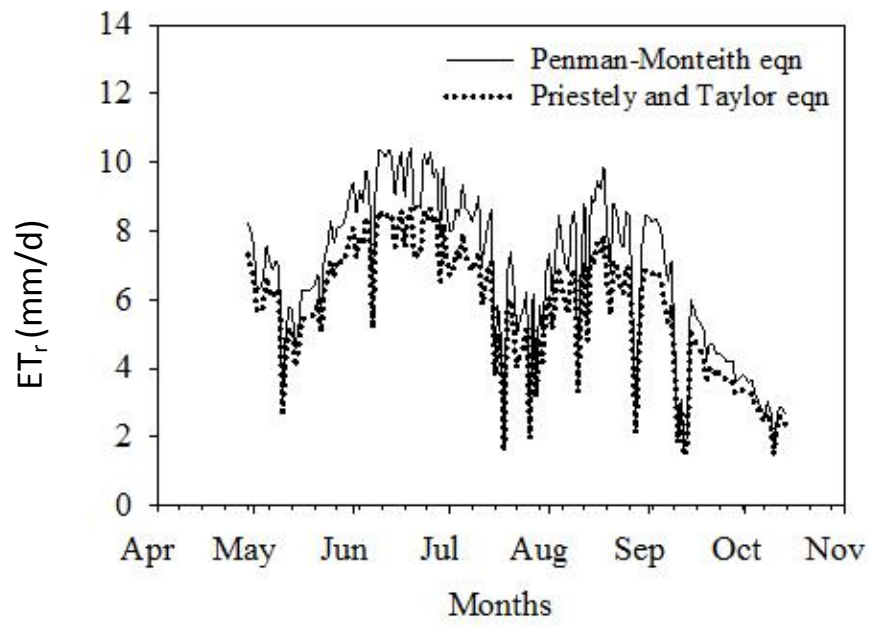

Figure 8. Comparison of daily average reference evapotranspiration values $\left(\mathrm{ET}_{\mathrm{r}} ; \mathrm{mm} \mathrm{day}^{-1}\right)$ using PM and PT methods during period from April 29 to October 14, 2013. 


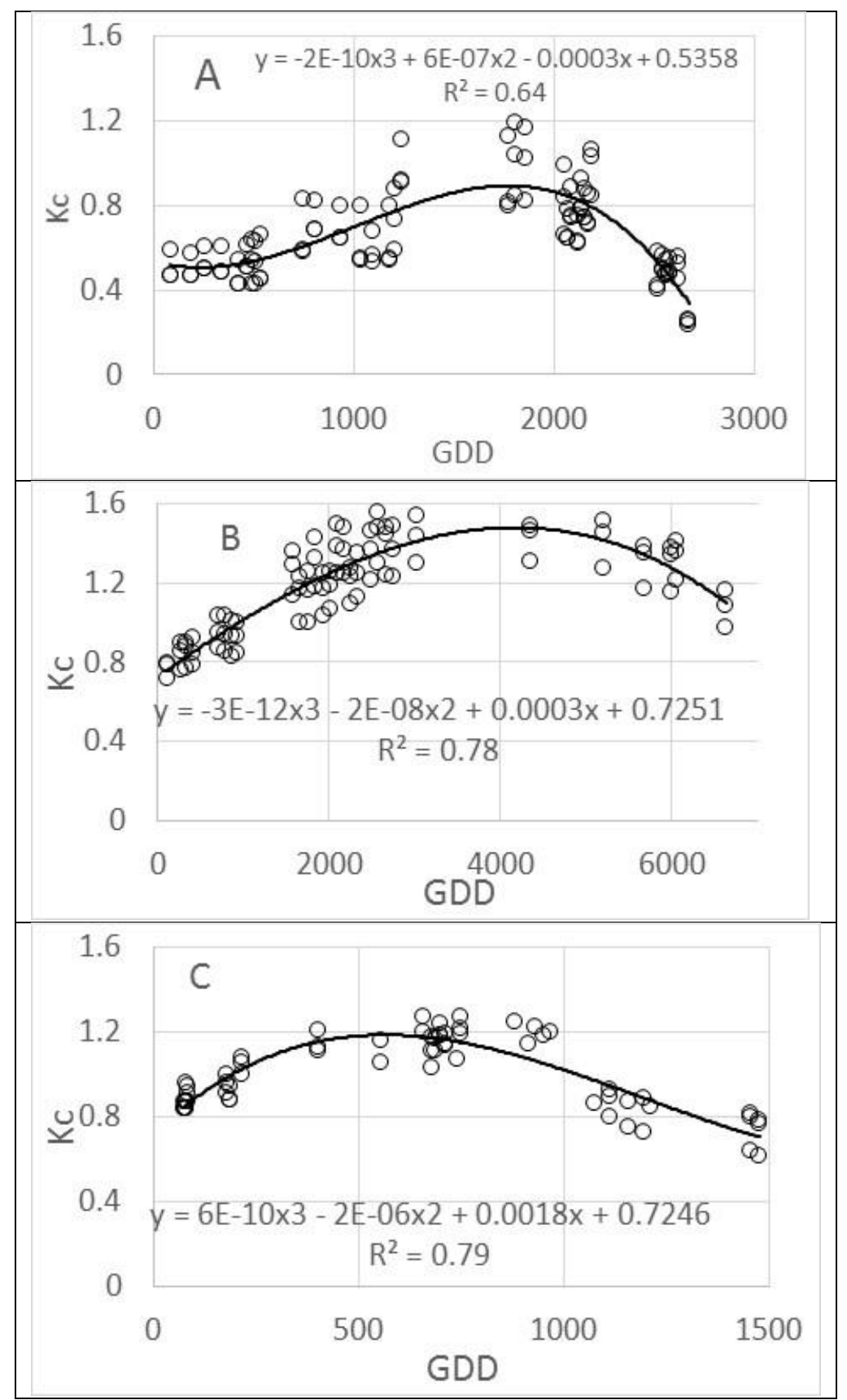

Figure 9. Crop coefficient $(\mathrm{Kc})$ versus growing degree days $\left(\mathrm{GDD} ;{ }^{\circ} \mathrm{C}\right)$ curves for drip irrigated greenhouse chile pepper under three different irrigation treatments (Control, PRDv, and PRDc) for growing seasons of (a) 2011, (b) 2013, and (c) 2014, respectively. PRD v $_{\mathrm{v}}$ is Partial rootzone drying vertically, and $\mathrm{PRD}_{\mathrm{c}}$ is Partial rootzone drying compartment. The $\mathrm{R}^{2}$ is significant at $\mathrm{P}<0.001)$ 
Table 1 New coefficients (A, B, C, and D), for the three soil water content $(\theta)$ sensors, coefficient of determination $\left(\mathrm{R}^{2}\right)$, and root mean square values (RMSE) between gravimetrically measured and sensor measured $\theta$

\begin{tabular}{|c|c|c|c|c|c|c|}
\hline depth & \multicolumn{3}{|c|}{ New calibration coefficients } & & \multirow[t]{2}{*}{$\mathrm{R}^{2}$} & \multirow[t]{2}{*}{ RMSE } \\
\hline & & TDR CS616 & & & & \\
\hline & A & B & $\mathrm{C}$ & $\mathrm{D}$ & & \\
\hline $0-15$ & 3.055010 & -0.221820 & 0.004263 & & 0.50 & 0.057 \\
\hline $15-30$ & 0.426198 & -0.034500 & 0.000969 & & 0.57 & 0.078 \\
\hline & & Hydra Probe & & & & \\
\hline $0-15$ & -0.042124 & 0.077619 & & & 0.85 & 0.022 \\
\hline $15-30$ & -0.756059 & 0.201531 & & & 0.81 & 0.001 \\
\hline & & 5TM & & & & \\
\hline $0-15$ & $7.696 \times 10^{-}$ & $-8.1 \times 10-4$ & $2.92 \times 10^{-2}$ & $5.3 \times 10^{-2}$ & 0.52 & 0.015 \\
\hline
\end{tabular}


Table 2. Detailed water balance analysis for greenhouse grown chile peppers during 2013. DAT indicates day since transplant; ETa is evapotranspiration, dS is the change in storage (Hydra sensor measured); DP is deep percolation; $\mathrm{SD}$ is standard deviation; $\mathrm{PRD}_{\mathrm{v}}$ is Partial rootzone drying vertically; and $\mathrm{PRD}_{\mathrm{c}}$ is partial rootzone drying compartment.

\begin{tabular}{|c|c|c|c|c|c|c|c|c|}
\hline \multirow{2}{*}{$\begin{array}{l}\text { DAT } \\
2013\end{array}$} & \multicolumn{2}{|c|}{ Irrigation $(\mathrm{cm})$} & \multirow{2}{*}{$\begin{array}{r}\text { ETa } \\
\text { Average }\end{array}$} & \multirow{2}{*}{$\begin{array}{r}(\mathrm{cm}) \\
\mathrm{SD}\end{array}$} & \multirow{2}{*}{$\begin{array}{c}\mathrm{dS} \\
\text { Average }\end{array}$} & \multirow{2}{*}{$\begin{array}{l}(\mathrm{cm}) \\
\mathrm{SD}\end{array}$} & \multirow{2}{*}{$\begin{array}{c}\text { DP } \\
\text { Average }\end{array}$} & \multirow{2}{*}{$\begin{array}{r}(\mathrm{cm}) \\
\mathrm{SD}\end{array}$} \\
\hline & Average & SD & & & & & & \\
\hline & & & Control & & & & & \\
\hline 43 & 24.46 & 0.00 & 15.57 & 0.03 & 1.01 & 0.02 & 10.44 & 3.62 \\
\hline 73 & 24.46 & 0.00 & 13.88 & 1.98 & 1.16 & 0.01 & 11.91 & 2.96 \\
\hline 104 & 24.46 & 0.00 & 15.44 & 0.02 & 1.09 & 0.01 & 10.42 & 3.53 \\
\hline 134 & 24.46 & 0.00 & 15.27 & 0.07 & 1.19 & 0.00 & 10.42 & 3.43 \\
\hline 163 & 13.98 & 0.00 & 4.77 & 0.05 & 1.40 & 0.01 & 6.77 & 1.45 \\
\hline 183 & 6.99 & 0.00 & 0.20 & 0.10 & 1.38 & 0.01 & 3.72 & 2.45 \\
\hline \multirow[t]{2}{*}{ Total } & 118.83 & 0.00 & 65.13 & 1.77 & 7.22 & 0.02 & 53.69 & 9.26 \\
\hline & & & PRDc & & & & & \\
\hline 43 & 17.12 & 0.00 & 14.39 & 0.02 & 0.85 & 0.01 & 1.88 & 0.02 \\
\hline 73 & 17.12 & 0.00 & 14.14 & 0.02 & 0.91 & 0.01 & 2.08 & 0.01 \\
\hline 104 & 17.12 & 0.00 & 14.19 & 0.03 & 0.70 & 0.01 & 2.23 & 0.03 \\
\hline 134 & 17.12 & 0.00 & 14.26 & 0.03 & 0.81 & 0.00 & 2.06 & 0.02 \\
\hline 163 & 9.79 & 0.00 & 6.74 & 0.03 & 0.94 & 0.00 & 2.11 & 0.02 \\
\hline 183 & 4.89 & 0.00 & 2.67 & 0.03 & 0.91 & 0.01 & 1.31 & 0.04 \\
\hline \multirow[t]{2}{*}{ Total } & 83.18 & 0.00 & 66.39 & 0.14 & 5.11 & 0.02 & 11.67 & 0.14 \\
\hline & & & PRDv & & & & & \\
\hline 43 & 24.46 & 0.00 & 16.71 & 0.02 & 1.03 & 0.01 & 6.73 & 0.02 \\
\hline 73 & 24.46 & 0.00 & 16.63 & 0.02 & 1.18 & 0.00 & 6.65 & 0.01 \\
\hline 104 & 24.46 & 0.00 & 16.52 & 0.03 & 1.13 & 0.00 & 6.81 & 0.03 \\
\hline 134 & 24.46 & 0.00 & 16.52 & 0.14 & 1.11 & 0.01 & 6.83 & 0.15 \\
\hline 163 & 13.98 & 0.00 & 5.27 & 0.06 & 1.70 & 0.01 & 7.01 & 0.05 \\
\hline 183 & 6.99 & 0.00 & 0.95 & 0.03 & 1.42 & 0.01 & 4.62 & 0.03 \\
\hline Total & 118.83 & 0.00 & 72.60 & 0.08 & 7.57 & 0.04 & 38.66 & 0.10 \\
\hline
\end{tabular}

Note: Significant differences were observed for amounts of daily and total irrigations, daily and total ET, daily and total dS, and daily and total DP at $\mathrm{P}<0.05$. 
Table 3. Detailed water balance analysis for greenhouse grown chile peppers during 2014. DAT indicates day since transplant; ETa is evapotranspiration, dS is the change in storage (Hydra sensor measured); DP is deep percolation; $\mathrm{SD}$ is standard deviation; $\mathrm{PRD}_{\mathrm{v}}$ is Partial rootzone drying vertically; and $\mathrm{PRD}_{\mathrm{c}}$ is partial rootzone drying compartment.

\begin{tabular}{|c|c|c|c|c|c|c|c|c|}
\hline \multirow{2}{*}{$\begin{array}{l}\text { DAT } \\
2014 \\
\end{array}$} & \multicolumn{2}{|c|}{ Irrigation $(\mathrm{cm})$} & \multicolumn{2}{|l|}{$\begin{array}{c}\mathrm{ETa} \\
(\mathrm{cm})\end{array}$} & \multicolumn{2}{|l|}{$\begin{array}{c}\mathrm{dS} \\
(\mathrm{cm})\end{array}$} & \multicolumn{2}{|l|}{$\begin{array}{c}\text { DP } \\
(\mathrm{cm})\end{array}$} \\
\hline & Average & $\mathrm{SD}$ & Average & SD & Average & SD & Average & $\mathrm{SD}$ \\
\hline & & & Control & & & & & \\
\hline 60 & 26.21 & 0.00 & 23.86 & 0.03 & 2.04 & 0.01 & 0.31 & 0.02 \\
\hline 105 & 26.21 & 0.00 & 24.02 & 0.03 & 1.91 & 0.03 & 0.29 & 0.01 \\
\hline 153 & 27.96 & 0.00 & 25.97 & 0.01 & 1.66 & 0.01 & 0.32 & 0.00 \\
\hline Total & 80.38 & 0.00 & 73.86 & 0.05 & 5.61 & 0.04 & 0.92 & 0.01 \\
\hline & & & PRDc & & & & & \\
\hline 60 & 18.35 & 0.00 & 17.44 & 0.01 & 0.91 & 0.01 & 0.00 & 0.00 \\
\hline 105 & 18.35 & 0.00 & 17.47 & 0.01 & 0.88 & 0.01 & 0.00 & 0.00 \\
\hline 153 & 18.35 & 0.00 & 17.32 & 0.01 & 1.03 & 0.01 & 0.00 & 0.00 \\
\hline Total & 55.04 & 0.00 & 52.23 & 0.02 & 2.81 & 0.02 & 0.00 & 0.00 \\
\hline & & & PRDv & & & & & \\
\hline 60 & 18.35 & 0.00 & 16.99 & 0.16 & 1.26 & 0.05 & 0.00 & 0.00 \\
\hline 105 & 18.35 & 0.00 & 16.71 & 0.18 & 1.54 & 0.04 & 0.00 & 0.00 \\
\hline 153 & 18.35 & 0.00 & 16.48 & 0.18 & 1.76 & 0.03 & 0.00 & 0.00 \\
\hline Total & 55.04 & 0.00 & 50.18 & 0.51 & 4.57 & 0.10 & 0.00 & 0.00 \\
\hline
\end{tabular}

Note: Significant differences were observed for amounts of daily and total irrigations, daily and total ET, daily and total dS, and daily and total DP at $\mathrm{P}<0.05$. 
Table 4 Reference evapotranspiration (ETr) values during three growing years using PenmanMonteith (PM), Priestley and Taylor (PT) equations, and actual evapotranspiration (ETa) from water balance

\begin{tabular}{|c|c|c|c|c|c|}
\hline \multirow[t]{2}{*}{ Year } & \multicolumn{2}{|c|}{ ETr $\quad(\mathrm{cm})$} & \multicolumn{3}{|c|}{$\underline{\mathrm{ETa}(\mathrm{cm})}$} \\
\hline & PM & PT & Control & PRDv & PRDc \\
\hline 2011 & 50.95 & 42.45 & $55.85 \mathrm{c}$ & $61.70 \mathrm{a}$ & $60.55 b$ \\
\hline 2013 & 64.06 & 53.71 & $65.13 b$ & $72.60 \mathrm{a}$ & $66.39 \mathrm{~b}$ \\
\hline 2014 & 53.71 & 46.59 & $73.86 \mathrm{a}$ & $50.18 \mathrm{c}$ & $52.23 \mathrm{~b}$ \\
\hline
\end{tabular}


Table 5 Crop coefficients $\left(\mathrm{K}_{\mathrm{c}}\right)$ calculated using measured crop ET and reference ET using Penman-Monteith equation versus growing degree days (GDD) relationship for greenhouse drip irrigated chile for all three irrigation treatments during the growing seasons of 2011, 2013, and 2014.

Equations for crop coefficient $\left(\mathrm{K}_{\mathrm{c}}=\right)$

\begin{tabular}{|c|c|c|c|}
\hline Treatments & 2011 & 2013 & 2014 \\
\hline Control & $-2 E-10 x^{3}+7 E-07 x^{2}-0.0002 x+0.5905$ & $-3 E-11 x^{3}-1 E-08 x^{2}+0.0005 x+0.7465$ & $9 E-10 x^{3}-3 E-06 x^{2}+0.0022 x+0.7267$ \\
\hline $\mathrm{R}^{2} / \mathrm{P}$ value & $0.82 /<0.001$ & $0.92 /<0.001$ & $0.89 /<0.001$ \\
\hline PRDv & $-2 E-10 x^{3}+7 E-07 x^{2}+0.0003 x+0.5158$ & $-1 E-11 x^{3}-1 E-07 x^{2}+0.0007 x+0.7652$ & $1 E-09 x^{3}-3 E-06 x^{2}+0.0022 x+0.6717$ \\
\hline $\mathrm{R}^{2} / \mathrm{P}$ value & $0.69 /<0.001$ & $0.91 /<0.001$ & $0.86 /<0.001$ \\
\hline PRDc & $-2 E-10 x^{3}+6 E-07 x^{2}-0.0003 x+0.501$ & $-2 E-11 x^{3}-2 E-08 x^{2}+0.0005 x+0.6731$ & $3 E-10 x^{3}-1 E-06 x^{2}+0.0015 x+0.7306$ \\
\hline $\mathrm{R}^{2} / \mathrm{P}$ value & $0.75 /<0.001$ & $0.91 /<0.001$ & $0.81 /<0.001$ \\
\hline
\end{tabular}

where $\mathrm{x}$ is $\operatorname{GDD}\left({ }^{\circ} \mathrm{C}\right)$ 